\title{
THE STUDY OF BEAM CONNECTION WITH DIAGONAL MODELS
}

\author{
Masdiana, Siti Nurjanah Ahmad, Sulha, M. Thahir Azikin, Ahmad Syarif Sukri \\ Associate Professor, Civil Engineering Department, Halu Oleo University, Indonesia
}

\begin{abstract}
The Technology of precast concrete growing rapidly. The concrere research has been aimed to create an innovation simplify and to reduce weaknesses of concrete include precast concrete. This study aims to research the connection of precast beams with combination notches type. This study used precast beams which dimensions were $20 \times 30 \times 270 \mathrm{~cm}, f^{\prime}(\mathrm{c})$ was $25 \mathrm{MPa}$. The precast beams which connection by diagonal types, the length of connection was $15 \mathrm{~cm}$ and $20 \mathrm{~cm}$. The samples used 3(three) beams ie. 2 (two) of beams precast as BM-15 and BM-20 which are connected by diagonal types with grouting OMPa and 1 (one) of monolith beam as BN. The results of researches that the strongest beam precast was BM-20 on 44,05 $\mathrm{kN}$ or 30,41\% than monolith beam (BN).
\end{abstract}

Keywords: Beam, Connection, Notch.

Cite this Article: Masdiana, Siti Nurjanah Ahmad, Sulha, M. Thahir Azikin, Ahmad Syarif Sukri, The Study of Beam Connection with Diagonal Models. International Journal of Civil Engineering and Technology 11(1), 2020, 158-164.

http://iaeme.com/Home/issue/IJCIET?Volume=11\&Issue=1

\section{INTRODUCTION}

Industrial Indonesia is a country most used concrete materials on a building. The concrete technology is growing rapidly which one of them is Precast. Precast is a technology used in concrete construction in which the strength of concrete is more than conventional concrete. Elly et.al (2000) said structural precast elements have some disadvantages, among others: Keep a strict monitoring on mainly connection area; Hauling distances not allowed far away; Availability equipment for handling and erection; The length and shape of the precast elements were restricted; required sufficient space for workers to connect precast and require a large area for manufacturing and stockyard.

Beams are structural elements that distribute the load from the floor to the column. The force of gravity on the beam can resist wind and seismic loads. It caused flexural and deformation. Flexural beams are a result of the strain due to external loads. It's difficult to know when beams in elastic condition. A need to ensure that beam flexural strength greater than the nominal strength. 
Precast concrete is made in manufacture. The manufacturing process is in factories, quality guaranteed and assembled at the construction site. Precast concrete manufactured by different spans and various forms of the cross-section. The determination system of the cross-sectional shape of precast influenced would be used. For example, a connection system between a beam and floor plate or joint between beams to columns. Required a detailed planning of and a watchful eye on used when connecting precast so that distribution of force between connections can occur.

In redistribution design on precast should notice e.i: static balance is always fulfilled, ability portal that does not change in lateral load, the plastic hinge can not be allowed occur on the base of the column and end of beams. Research by (Masdiana, et.al, 2016) $[7,8]$ proved that beams connected with the notches model that maximum load for BN was $60,2 \mathrm{kN}$; BTK-20 was $73,51 \mathrm{kN}$ and BTK-20 was $75,30 \mathrm{kN}$. The strength BTK-15 was $20.06 \%$ of monolith beams (BN), while the strength of BTK20 was $23 \%$ of BN. This research-based beam connection with combinations of notches model.

\section{MATERIALS AND TEST METHODS}

\subsection{Mix Design}

The first step of researches was material tests before we doing the strength tests of beams connections. The result of material test was can be seen in the table:

Table 1 Mix Design

\begin{tabular}{cccccc}
\hline $\begin{array}{c}\mathbf{f} \mathbf{c} \\
(\mathbf{M p a})\end{array}$ & $\begin{array}{c}\text { W/C } \\
(\%)\end{array}$ & $\begin{array}{c}\text { Water } \\
\left(\mathbf{K g} / \mathbf{m}^{2}\right)\end{array}$ & $\begin{array}{c}\text { Cement } \\
(\mathbf{K g})\end{array}$ & $\begin{array}{c}\text { Sand } \\
(\mathbf{K g})\end{array}$ & $\begin{array}{c}\text { Aggregate } \\
(\mathbf{K g})\end{array}$ \\
\hline 25 & 47,4 & 161,30 & 340 & 640,94 & 1187,75 \\
\hline
\end{tabular}

The grouting composition was grouting: water: screening was $6,25: 1: 1,125$. The strength of the grouting design was $40 \mathrm{MPa}$.

\subsection{Testing and Measurement}

After specimen tests, the next step was made joint specimens. The specimens consist of 3 (three) beams: 1 (one) was monolith beam $(\mathrm{BN}), 1$ (one) was beam precast with connections length of the notch was $15 \mathrm{~cm}$ and (BTK-15) and 1 (one) was precast beam with connections with a length of notch was $20 \mathrm{~cm}$ (BTK-20). Dimensions beams were $2700 \mathrm{~mm}$ x $250 \mathrm{~mm}$ x $300 \mathrm{~mm}$. Main reinforcement used D10 and reinforcement stirrup D6 as shown in Figure $1-$ Figure 3.
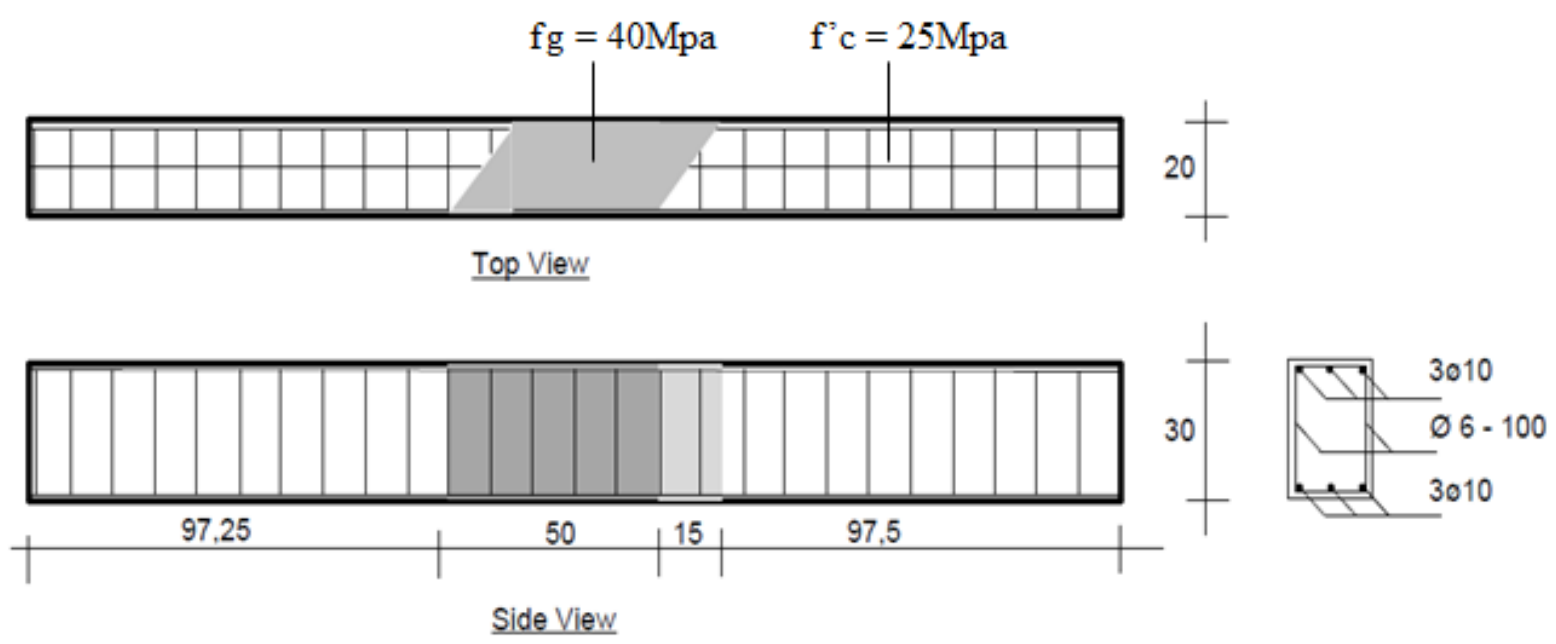

Figure 1 Precast Beam (BM-15) 


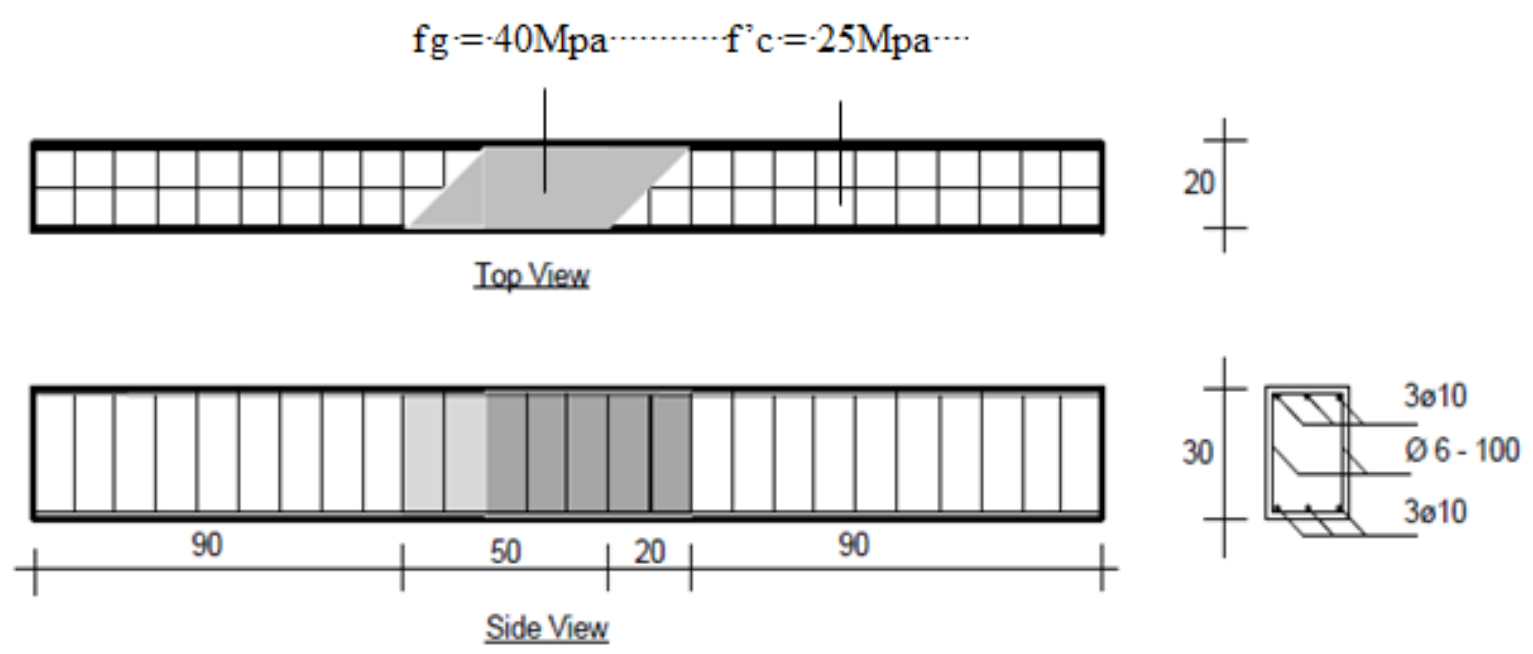

Figure 2 Precast Beam (BM-20)

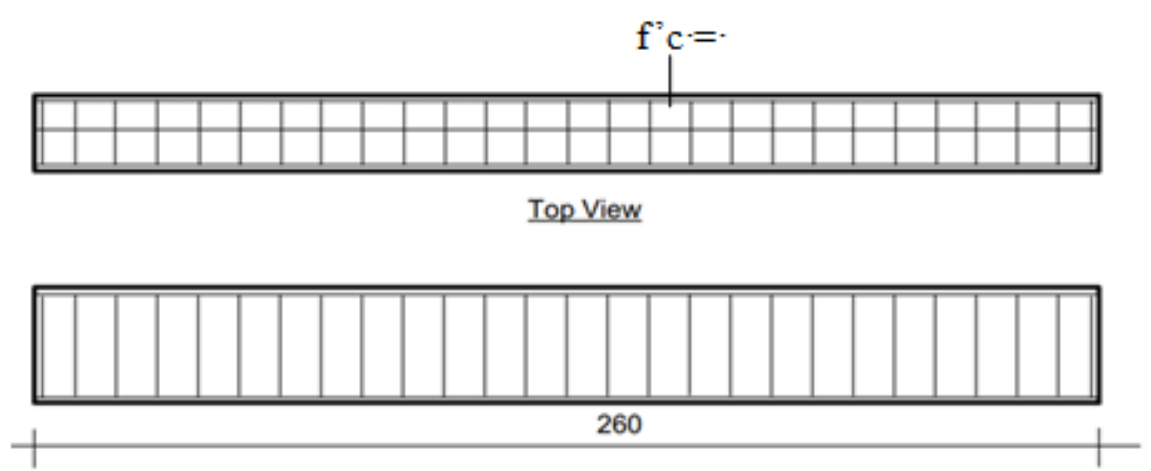

${ }^{20}+$

Side View

Figure 3 Monolith Beam (BN)

\section{RESULTS AND DISCUSSION}

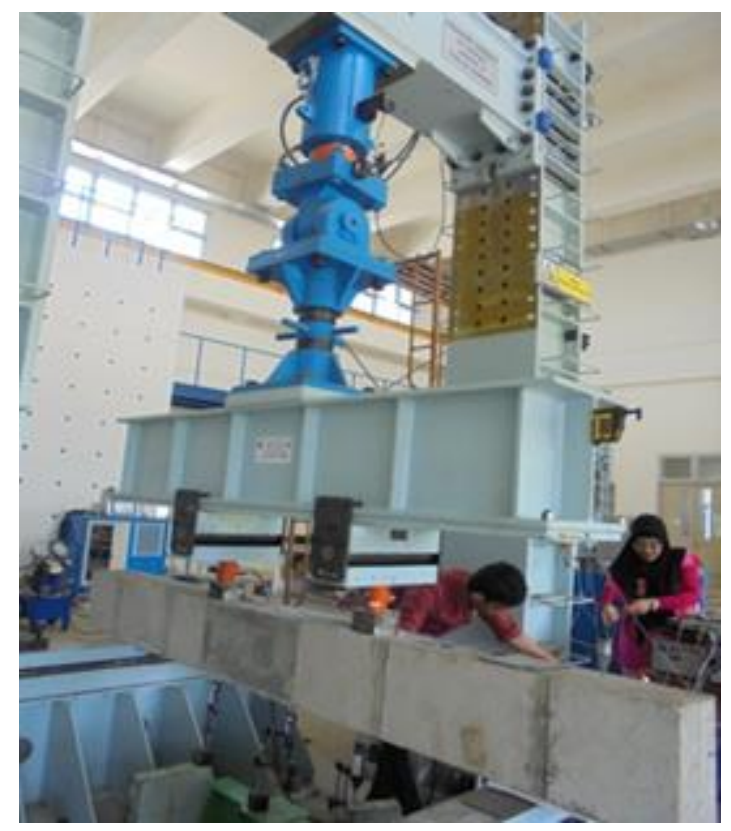



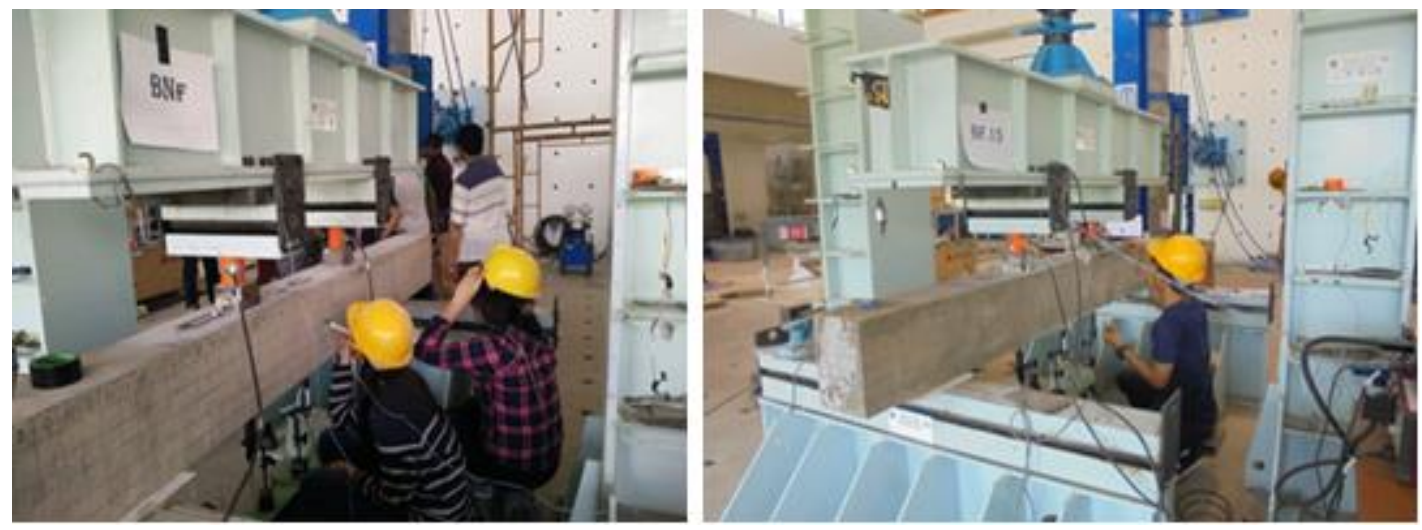

Figure 4. Beam test

Figure 4 shows the monolith beam which was f'(c) 25 Mpa. Figure 2 - Figure 3 show precast beams used combination notch type which length of the notch was $20 \mathrm{~cm}$ and $15 \mathrm{~cm}$. The precast beams (BM) were connected after 28 days. The concrete beam was connected by a grouting system with $\mathrm{f}^{\prime}(\mathrm{g})$ was $40 \mathrm{Mpa}$.

The welding system and grouting used to connected the reinforcement. The aims of precast research were easy workability. The innovation of precast connections and behavior of notch combination type. The flexural testing beams used two-point load method based on SNI $4431: 2011$.

\subsection{Analysis of Data}

Table 2 Results of testing Load and Deflection

\begin{tabular}{cccccccc}
\hline \multirow{2}{*}{ Specimen } & \multicolumn{2}{c}{$\begin{array}{c}\text { Load } \\
(\mathbf{k N})\end{array}$} & \multicolumn{2}{c}{$\begin{array}{c}\text { Deflection } \\
(\mathbf{m m})\end{array}$} & \multicolumn{2}{c}{$\begin{array}{c}\text { Design Load } \\
(\mathbf{k N})\end{array}$} \\
\cline { 2 - 8 } & $\mathbf{P}_{\mathbf{c r}}$ & $\mathbf{P}_{\mathbf{u}}$ & $\boldsymbol{\Delta} \mathbf{c r}$ & $\boldsymbol{\Delta u}$ & $\mathbf{P}_{\mathbf{c r}}$ & $\mathbf{P}_{\text {leleh }}$ & $\mathbf{P}_{\text {ult }}$ \\
\hline $\mathrm{BN}$ & 12,91 & 30,61 & 1,40 & 8,09 & & & \\
$\mathrm{BM}-15$ & 12,79 & 44,05 & 2,73 & 13,83 & 19,54 & 39,72 & 41,68 \\
$\mathrm{BM}-20$ & 13,08 & 39,92 & 1,82 & 11,36 & & & \\
\hline
\end{tabular}

From Table 2 know that the best precast was BM-15 on $44,05 \mathrm{kN}$ or $43,91 \%$ than the monolith beam (BN) while BM-20 has $39,92 \mathrm{kN}$ or $30,41 \%$ than $\mathrm{BN}$. The precast beam does not reach in collapse phase but the samples can exceed of design of capacity. The next steps were the analysis of the data as follows :

From Table 2 result of results, we can make a graph which compressive strength and deflection as follows :

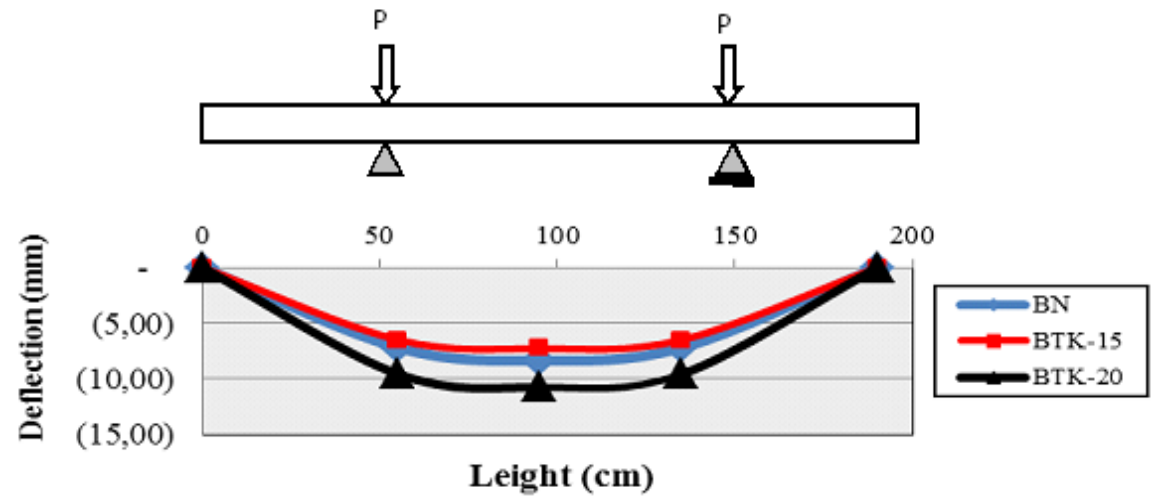

Figure 5 Deflection on beams 
Figure 5 was a result of load-deflection on beams. In figure can be seen that the load was given on the test object still grow up to having collapsed cause the strange gauge was on reinforcement and concrete didn't show it.

\section{The results crack pattern as shown below.}

In Figure 6 shows that the first crack occurred when Pcrack on BN was 13,21 kN. The average length of cracks was $21 \mathrm{~cm}$ which happened in the LVDT-1 area, LVDT-2 area, and LVDT-3 area. The ultimate load (Pult) on BN was 30,61 kN, after that the BN was in collapse condition. The cracks pattern were flexural cracks.

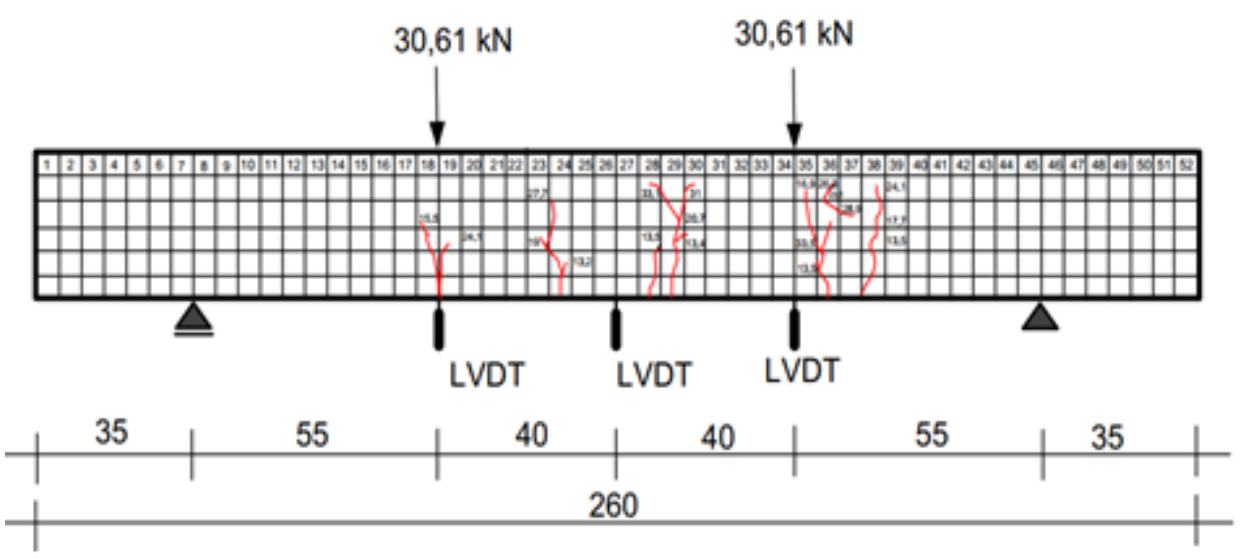

Figure 6.Pattern cracked on BN

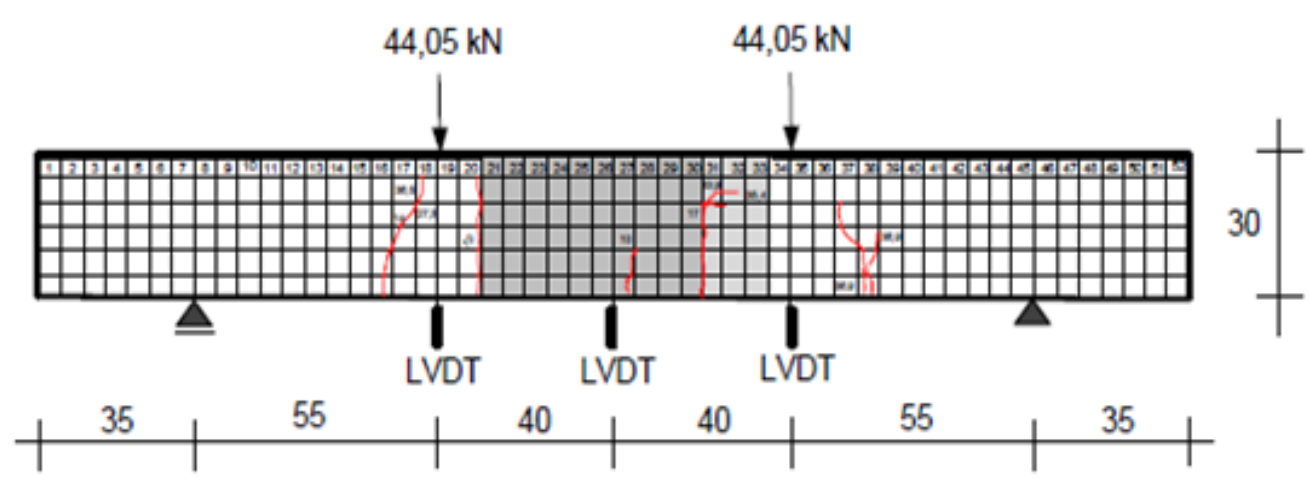

Crack pattern

Figure 7. Pattern cracked on BM-15

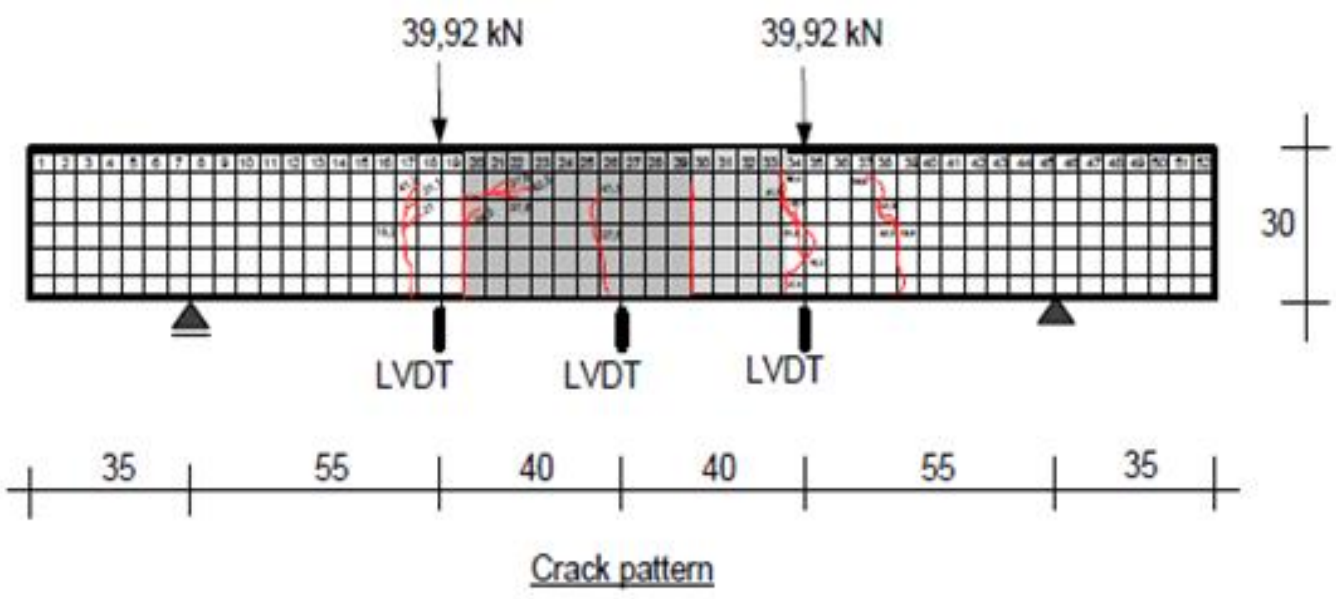

Figure 8. Pattern cracked on BM-20 
In Figure 7 shows that the first crack occurred when Pcrack (BM-15) was $10,07 \mathrm{kN}$. The average length of crack was $25 \mathrm{~cm}$ which happened in the LVDT-1 area where in connection area, LVDT-2 area, and LVDT-3 area. At first, the crack pattern were flexural cracks until the maximum load given then the pattern of the cracks turns into shear cracks. The ultimate load (Pult) on BM-15 was 44,05 kN.

In Figure 8 shows that the first crack occurred when Pcrack (BF-20) was 15,2 kN. The average length of cracks was $20 \mathrm{~cm}$ which happened in the LVDT-1 area, LVDT-2 area, and LVTD-3 area. The ultimate load (Pult) on BM-20 was $39,92 \mathrm{kN}$. It could be seen that cracks on precast occurred a few cracks. The strain gauge on precast beams and reinforcement couldn't reach over and the precast beams have not collapsed.

\section{The result of the strength of beam connection tests was obtained as follows:}

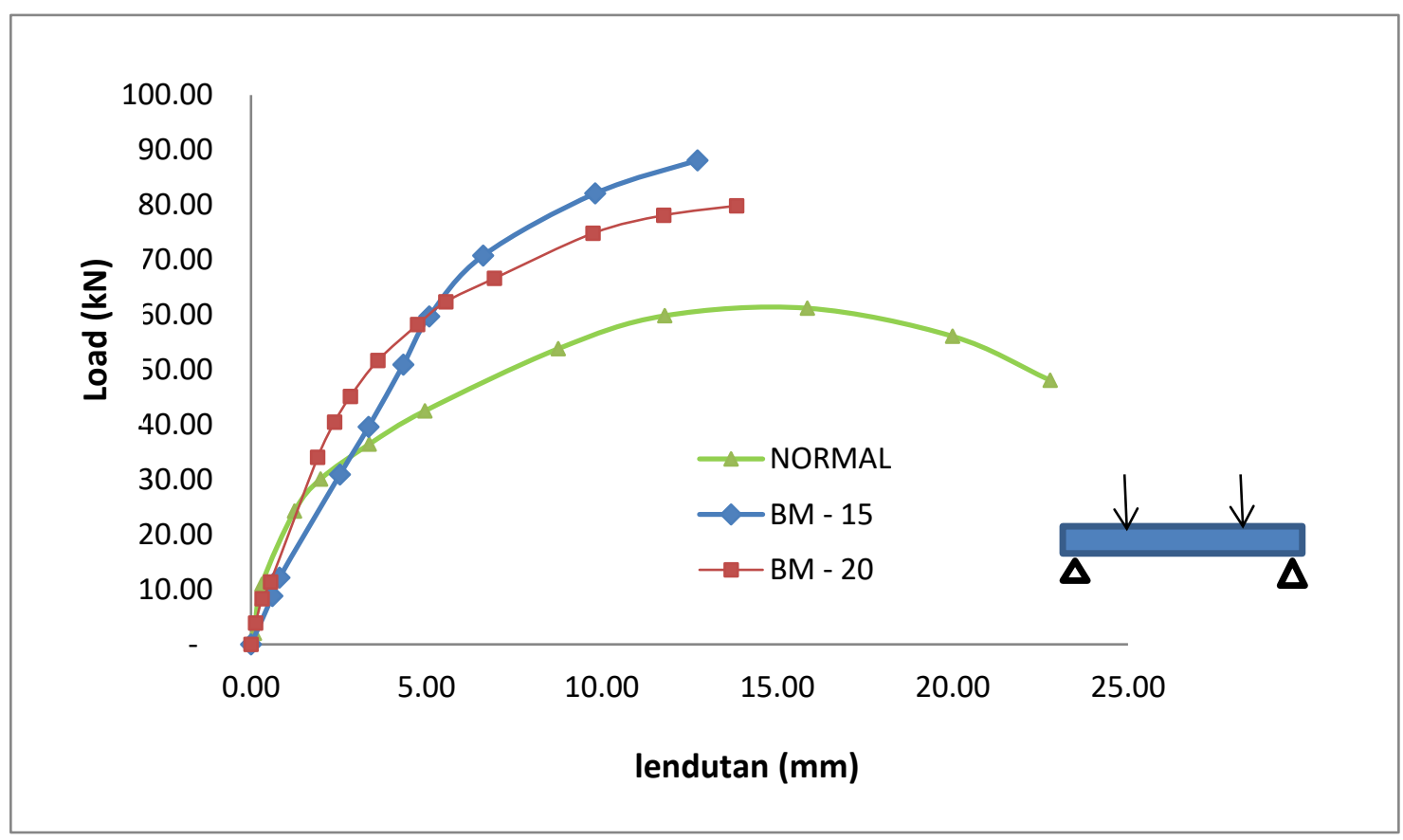

Figure 9. Load - Deflection curve

Figure 9 can be seen as a curve of load vs deflection. From three curves known that when the load was $20 \mathrm{kN}$. The beams still in an elastic condition which deflection was average 2 $\mathrm{mm}$. The strength of BN was increased until 30,61 kN and being collapsed at last. From observations of crack on precast beams known that the strength of precast beams still

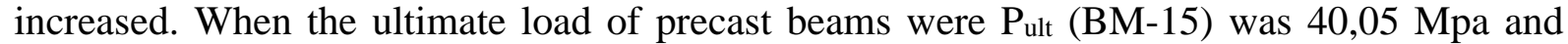
Pult (BM-20) was 39,92 Mpa. The precast beams could exceed the research design and precast haven't collapsed yet. While the monolith beam has collapsed at $\mathrm{Pult}_{\mathrm{t}}(\mathrm{BN})$ was 30,61 Mpa.

\section{CONCLUSION}

The aims of the strength of precast beams $(\mathrm{BM})$ was could exceed the monolith beam $(\mathrm{BN})$. The monolith beam (BN) and the precast beam (BF-20) haveflexural cracks can be concluded that the beams were inflexural failure condition. While BM-15 was flexural cracks at first and turned into shear cracks at last so can be concluded that BM-15 has shear failure condition. When the load was zero on precast beams then the cracks would re-close. It can be concluded that the beam weren't collapse. 
The welding system on reinforcement could distribute compressive strength well and grouting system at concrete could distribute tensile strength well which resulted in flexural pattern cracks on precast beams.

The conclusion was that the strength of precast beams (BM) connected with diagonal notches models could exceed the monolith beam (BN).

\section{REFERENCES}

[1] Balai Standardisasi Nasional SNI 1726 : 2012. Tata Cara Perencanaan Ketahanan Gempa untuk Struktur Bangunan Gedung dan Non Gedung.

[2] Namdar, abdoullah., Darvishi,Ershad., Feng,Xiong. (2016).Effect of Flexural Crack on Plain Concrete Beam Failure Mechanism A Numerical Simulation. Fraturra ed Integrita Strutturale,36 DOI : 10.3221/IGF-ESIS.36.17

[3] Yun, Hyundo., Junesu,Kim (2012). Effect of Cement Composite's Ductility on the Flexural and Cracking Behaviour of Reinforced Cement Composite Beams. Mechanics and Materials. Vol 204-208. pp 3325-2228.

[4] Zhou, Hongyu., Li,Zhenbou., Guo,Erwei., Zhang, Jing. (2012). Ekxperimental Study on Size Effect of Flexural Capacity of RC Free Beams. Mechanics and Materials. Vol 94-96. pp 262-268.

[5] Qin,Wen-yue., Chen,Yu-Liang., Chen,Zong-Ping,. (2012). Experimental Study on Flexural Behaviour of Steel Reinforced Recycle Coarsed Aggregate Concrete Beams. Mechanics and Materials. Vol 166-169. pp 1614-1619.

[6] Mardewi Jamal, Herman Parung, HM, Wihardi Tjaronge, Victor Sampebulu, (2015). Behavior of The Precast and Monolith Concrete on Beam-Colomn Joints Under Cyclec Loading. Proceedings of yhe $2^{\text {nd }}$ MICCE.

[7] Mardewi Jamal ; Herman Parung ; M.W Tjaronge Wihardi dan Victor Sampebulu. 2014. Ductility of The Precast and Monolith Concrete on Beam Column Joints Under Cyclic Loading. ARPN Journal of Engineering and Applied Sciences. Vol. 9, No. 10.

[8] Masdiana, Herman Parung, M.W. Tjaronge, Rudy Djamaluddin (2016) Experimental Study On Cracks In Beams Connection With Nothes Models. Proceedings The International Seminar on Infrasructure Development (ISID) September 22 ${ }^{\text {nd }}$, pp 379-384.

[9] Masdiana, Herman Parung, M.W. Tjaronge, Rudy Djamaluddin (2019) Behaviour of Precast Interior Joint Using A Notch Connection Under Cyclic Loading. Journal of Engineering and Applied Sciences 14(5), pp 1636-1644.

[10] M. Thahir Azikin, Ramli Rahim, Sakti Adji Adisasmita, Sumarni Hamid (2017) Study of Heterogeneous Trafiic Characteristic Model on Arterial Roads Based on Driver Behaviour (Case Studi : Driver Behaviour in Makassar). IJCIET Vol 8 Issue 8. Pp. 379388

[11] SNI 4431 : 2011. Cara Uji Kuat Lentur Beton Normal dengan Dua Titik Pembebanan. 